\title{
Yield and postharvest of 'BRS Platina' banana not irrigated under different types of soil mulches
}

\author{
Bárbara Nogueira Souza Costa ${ }^{1}$ (D), Irton de Jesus Silva Costa² (D), Rafael Azevedo Arruda de Abreu² (iD), \\ Evaldo Tadeu Melo² (D), Deniete Soares Magalhães² (D), Leila Aparecida Salles Pio ${ }^{2, \star}$ (D), Moacir Pasqual (D) \\ 1. Centro Universitário Una - Departamento de Agricultura - Pouso Alegre (MG), Brazil. \\ 2. Universidade Federal de Lavras - Departamento de Agricultura - Lavras (MG), Brazil. \\ Received: May 20, 2020 | Accepted: Dec. 7,2020 \\ Section Editor: Osvaldo Guedes Filho \\ *Corresponding author: leilapio.ufla@gmail.com \\ How to cite: Costa, B. N. S., Costa, I. J. S., Abreu R. A. A, Melo E. T., Magalhães D. S., Pio L. A. S. and Pasqual, M. (2021). Yield and postharvest \\ of 'BRS Platina' banana not irrigated under different types of soil mulches. Bragantia, 80, e0821. https://doi.org/10.1590/1678-4499.20200251
}

\begin{abstract}
Banana (Musa spp.) is a crop with outstanding economic and social expression throughout the world. The objective of this study was to investigate the effect of different mulches types in growth production and postharvest of banana 'BRS Platina' not irrigated. The experiment was conducted in the farm of the Federal University of Lavras (UFLA). Micropropagated banana plants of the cultivar BRS were planted in the field with a spacing of $2.5 \times 3.0 \mathrm{~m}$ (1333 plants $\cdot \mathrm{ha}^{-1}$ ), without irrigation. About 20 days after planting, different mulches were installed: black polyethylene films, double-sided polyethylene films (white and black), organic mulch (from the own crop) and control (bare soil). The experimental was set up in a randomized block design with four treatments, six blocks and six plants per treatment, totaling 144 plants. Among the six plants used in each treatment, two constituted the border, therefore four plants were evaluated. The analysis performed in the first and second crop were: growth analysis, postharvest quality, production and productivity. Both organic and inorganic (plastic film) mulch provide greater growth and yield of banana 'BRS Platina' not irrigated, in two years of production and can be used in the cultivation of this crop.
\end{abstract}

Key words: plastic film, polyethylene, Musa spp.

\section{INTRODUCTION}

Banana (Musa spp.) is a crop with outstanding economic and social expression throughout the world. It is an important source of food and one of the fruits with the highest production and consumption among tropical fruit trees.

Mulching is the process of covering the soil surface around the plants with an organic or synthetic material to create congenial condition for plant growth, development and efficient production (Bakshi et al. 2015). There are different types of mulches, such as inorganic (gravel, pebbles or polyethylene film) and organic (wood, bark or leaves, used individually or in mixtures) (Ni et al. 2016).

Plastic film mulching has become a globally applied agricultural practice (Steinmetz et al. 2016). In China, it is estimated that about $15-19 \%$ of its arable land is currently cultivated under plastic film mulch (Wang et al. 2016). Its use aims to improve the soil environment, thus making it more beneficial to plant growth and increasing water use efficiency in semiarid regions (Ekebafe et al. 2011), once it can conserve soil moisture, maintain soil temperature and reduce fertilizers leaching. Mulching can also promote early harvest of crop and improve yield and fruit quality (Aman et al. 2018). Therefore, the current global usage of plastic mulch films is enormous and has been increasing in recent years (Brodhagen et al. 2017).

Organic mulches are those natural origin materials which can decompose naturally. Leaves are beneficial for soil; they contribute with nutrients when used as mulch. (Ranjan et al. 2017). Organic mulch promotes restoration of degraded soils 
and improves soil fertility, leading to greater crop productivity (Fang et al. 2007; Kader et al. 2017). They also regulate soil temperature, improve nutrient availability and absorption by roots and encourage soil biological activity (Liang et al. 2002; Pervaiz et al. 2009; Pakdel et al. 2013).

Technologies that optimize water resources are of extreme importance, since agriculture success is totally dependent on this resource. Several old techniques have been rescued and optimized, as the use of mulches. Recent studies show the efficiency of the plastic film mulch on the growth and yield of different cultures, such as mango, banana, papaya and pineapple, according to the National Committee on Plasticulture Applications in Horticulture (Bhattacharya et al. 2018).

Therefore, the objective of this study was to investigate the effect of different mulches types in growth, production and postharvest of banana 'BRS Platina' not irrigated.

\section{MATERIAL AND METHODS}

The experiment was conducted at the farm of the Federal University of Lavras (UFLA), located in the city of Lavras, southern Minas Gerais, from 2015 to 2017 The Köppen climate classification for this region is Cwa - subtropical climate ( $21^{\circ} 14^{\prime} \mathrm{S}, 45^{\circ} 00^{\prime} \mathrm{W}$ and $918 \mathrm{~m}$ of average altitude), i.e., a subtropical climate with cold and dry winters and warm and moist summers (Köppen and Geiger 1928). The average annual temperature in 2015,2016 and 2017 was $21.4,21.1$ and $20.8^{\circ} \mathrm{C}$ with minimum average temperature $16.6^{\circ} \mathrm{C}$ in $2015,16.2^{\circ} \mathrm{C}$ in 2016 and $15.8^{\circ} \mathrm{C}$ in 2017 and average maximum temperature $27.9^{\circ} \mathrm{C}$ in $2015,27.9^{\circ} \mathrm{C}$ in 2016 and $27.6^{\circ} \mathrm{C}$ in 2017 (Fig. 1). The sum of rainfall was $1246.00 \mathrm{~mm}$ in 2015, $1240.60 \mathrm{~mm}$ in 2016 and $1097.00 \mathrm{~mm}$ in 2017 (Table 1). The soil in the study area was classified as dystrophic Red Latosol clayey texture (Embrapa 2013), with 2.23 dag.kg-1 of organic matter. Before implementing this experiment, the area was cultivated with physic nut (Jatropha curcas L.).

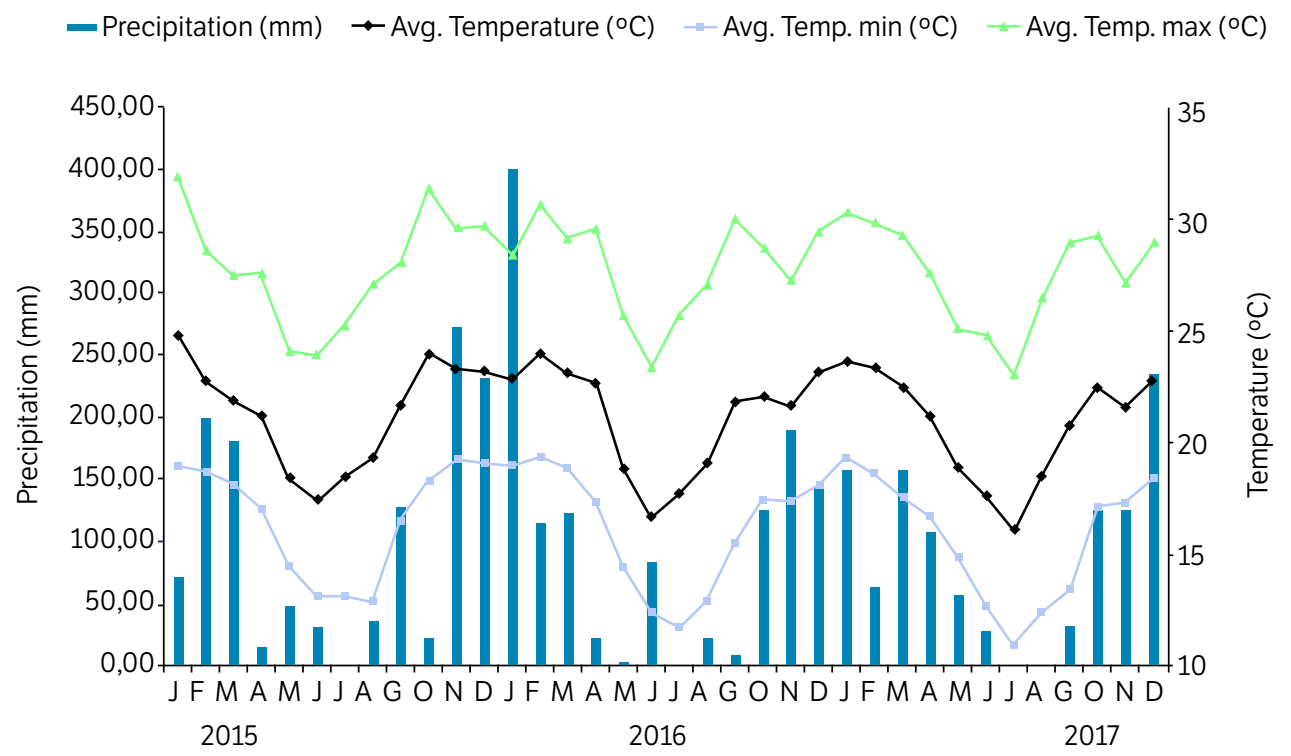

Figure 1. Climatic data from January 2015 to December 2017 in Lavras, Minas Gerais, Brazil. (INMET, 2020)

Soil preparation was carried out with a plowing and two harrowing, followed by the grooving in lines with a depth of $20 \mathrm{~cm}$. Later, micropropagated banana plants cultivar 'BRS Platina' were planted in the field in November 5th of 2015 with a spacing of $2.5 \times 3.0 \mathrm{~m}$ (1333 plants $\left.\cdot \mathrm{ha}^{-1}\right), 2.5 \mathrm{~m}$ between lines and $3.0 \mathrm{~m}$ between plants, totaling an area of $1,080 \mathrm{~m}^{2}$, without irrigation. About 20 days after planting, different mulches were installed: black polyethylene films, doublesided polyethylene film (white and black), organic mulch and control (bare soil). For the organic mulch, cultural remains from another banana plantation near the experiment area were used, in the first and in the second crop. In the second crop cultural 
remains of the culture itself were also used. The organic mulch used in the two years of production totally covered the soil in the planting line in the same width as the plastic films. When the organic mulch was decomposed it was replaced so that there was total soil coverage in the planting line. The plastic films ( $1.60 \mathrm{~m}$ width) were stretched on the planting line, cuts were made in the position of each plant, then the planting line was covered by plastic and the edges of the plastic were fixed with the soil.

Table 1. $\alpha$-amylase activity and other nutritional ingredients contents of normal seeds with no chalkiness and three grades of chalky seeds.

\begin{tabular}{|c|c|c|c|c|c|}
\hline Year & Months & Precipitation (mm) & Year & Months & Precipitation (mm) \\
\hline 2015 & November & 273.80 & 2017 & January & 157.90 \\
\hline 2015 & December & 232.90 & 2017 & February & 64.10 \\
\hline 2016 & January & 400.60 & 2017 & March & 158.60 \\
\hline 2016 & February & 114.90 & 2017 & April & 108.30 \\
\hline 2016 & March & 122.80 & 2017 & May & 57.60 \\
\hline 2016 & April & 22.20 & 2017 & June & 29.00 \\
\hline 2016 & May & 4.30 & 2017 & July & 0.00 \\
\hline 2016 & June & 84.20 & 2017 & August & 1.40 \\
\hline 2016 & July & 0.00 & 2017 & September & 32.60 \\
\hline 2016 & August & 22.60 & 2017 & October & 125.30 \\
\hline 2016 & September & 8.60 & 2017 & November & 126.40 \\
\hline 2016 & October & 125.20 & 2017 & December & 235.80 \\
\hline 2016 & November & 190.20 & & & \\
\hline 2016 & December & 145.00 & & & \\
\hline
\end{tabular}

Source: INMET, 2020.

The management practices carried out were a fertilization at planting and four cover fertilizations, two at the first crop, two months after planting and in the flowering of the plants. The other two were in the second crop at harvest and three months after harvesting the first crop. The defoliation and thinning happened in the field every 15 days and, if necessary, these procedures were performed, this management was adopted for the first and second crops. Thinning was carried out on the suckers 20 to $30 \mathrm{~cm}$.

Regarding the banana plant climatic requirements, the optimum temperature for the normal development is around $28^{\circ} \mathrm{C}$. The range of 15 to $35^{\circ} \mathrm{C}$ of temperature is considered the extreme limits for exploration of the culture. The largest banana production is associated with a total annual rainfall of $1,900 \mathrm{~mm}$, well distributed throughout the year, that is, representing $160 \mathrm{~mm} / \mathrm{month}$ and $5 \mathrm{~mm} /$ day, with annual average relative humidity above $80 \%$. The photosynthetic activity accelerates rapidly when lighting is in the range of 2,000 to 10,000 lux (Borges and Souza 2004).

The experiment was set up in a randomized block design with four treatments, six blocks and six plants per treatment, totaling 144 plants. Among the six plants used in each treatment, two constituted the border, therefore four plants were evaluated. The data was submitted to analysis of variance (ANOVA) and the means compared by Tukey's test at 5\%of significance level using the statistical program SISVAR (Ferreira 2011).

The analysis performed in the first and second crop were:

\section{Growth analysis}

The plants were evaluated for leaf number (unit), plant height $(\mathrm{cm})$, pseudostem diameter $(\mathrm{cm})$ and suckers number (unit) over 5 monthly evaluations. The plants were evaluated from 60 days after planting to 180 days in the first crop. With regards to the second crop after 120 days planting, the first suckers emerged that would give succession to the banana plantation, from that the mother plant and the daughter plant were evaluated simultaneously, until the mother plant bloomed. Later, only the daughter plant was evaluated from 120 days after planting up to 240 days, also until the plant bloomed. 


\section{Postharvest quality}

Samples were taken (one hand) from the total of bunches harvested from the experiment at the maturation stage six, according Von Loesecke's (1950) scale. Physical analysis in the fruits were performed, the length and diameter (mm) were measured with a pachymeter and the following chemical parameters were analyzed on the fruit pulp: soluble solids (SS), in refractometer, with results expressed in ${ }^{\circ}$ Brix; titratable acidity (TA), determined according to the Association of Official Analytical Chemists (AOAC) expressed in \% of citric acid per $50 \mathrm{~mL}$ of pulp, determined by titration with sodium hydroxide $(0.1 \mathrm{~N})$ using $1 \%$ phenolphthalein as indicator, the soluble solids/titratable acidity ratio (SS/TA).

\section{Production and Productivity}

The harvests were carried out in November 2016 and 2017. The number of hands (NH) was determined by the average number of hands obtained in the bunches collected in the plot. The number of fruits per hands (NFH) was determined by the average number of bananas obtained in each plot harvested in the plot. The production was obtained from the average of the weights of hands collected in the plot and the productivity $\left(\mathrm{Kg}_{\mathrm{ha}}{ }^{-1}\right)$ was obtained from the average weights of hands collected in the plot multiplied by the number of plants (1333 plants $\left.\cdot \mathrm{ha}^{-1}\right)$ (Lorena et al. 2016).

\section{RESULTS AND DISCUSSION}

\section{Growth analysis}

Most of the growth characteristics did not differ significantly for the interaction between mulches and evaluation period. Therefore, these factors were evaluated separately (Table 2 and 3 ).

Table 2. Plant height (PH), pseudostem diameter (PD), sucker number (SN) and leaf number (LN) of de Musa spp. of the first and second crop, under different mulches.

\begin{tabular}{|c|c|c|c|}
\hline \multirow{2}{*}{ Mulches } & $\mathrm{PH}(\mathrm{cm})$ & PD (cm) & SN (unit) \\
\hline & \multicolumn{3}{|c|}{ First crop } \\
\hline Control (bare soil) & $1.38 \mathrm{~b}$ & $44.12 b$ & $1.66 \mathrm{~b}$ \\
\hline Organic mulch & $1.57 a$ & $52.12 a$ & $2.30 a$ \\
\hline Plastic film (white and black) & $1.53 a$ & $49.81 a$ & $2.18 a$ \\
\hline Plastic film (black) & $1.54 a$ & $51.45 a$ & $2.24 a$ \\
\hline CV (\%) & 10.19 & 12.46 & 30.64 \\
\hline \multirow{2}{*}{ Mulches } & $\mathrm{PH}(\mathrm{cm})$ & PD (cm) & SN (unit) \\
\hline & \multicolumn{3}{|c|}{ Second crop } \\
\hline Control (baresoil) & $2.28 \mathrm{c}$ & 69.81b & $13.80 \mathrm{~b}$ \\
\hline Organic mulch & $2.69 a$ & $80.99 a$ & $14.19 b$ \\
\hline Plastic film (white and black) & $2.51 \mathrm{~b}$ & $79.15 a$ & $16.19 a$ \\
\hline Plastic film (black) & $2.45 b$ & $77.38 a$ & $17.02 a$ \\
\hline CV (\%) & 8.05 & 6.96 & 13.86 \\
\hline
\end{tabular}

*Means followed by the same letter within columns are not significantly different by Tukey's test $(p \leq 0.05)$.

All the mulches increased plant height, pseudostem diameter and suckers number in relation to control in the first crop. In the second crop, the organic mulch provided higher plant height compared to the other treatments and both plastic films increased the plant height compared to control. Besides, all the mulches provided increase in the pseudostem diameter. The plastics films increased in leaf number in comparison to the other treatments (Table 2). 
Table 3. Plant height (PH), pseudostem diameter (PD), sucker number (SN) and leaf number (LN) of de Musa spp. of the first and second crop at the periods of evaluation.

\begin{tabular}{|c|c|c|c|}
\hline \multirow{2}{*}{ Evaluations period (days) } & $\mathrm{PH}(\mathrm{cm})$ & PD (cm) & SN (unit) \\
\hline & \multicolumn{3}{|c|}{ First crop } \\
\hline 60 & $0.85 \mathrm{e}$ & $29.04 d$ & $0.00 e$ \\
\hline 90 & $1.24 d$ & $40.57 c$ & $2.20 c$ \\
\hline 120 & $1.60 c$ & $53.62 b$ & $3.58 \mathrm{~b}$ \\
\hline 150 & $1.87 \mathrm{~b}$ & $60.48 a$ & $4.10 a$ \\
\hline 180 & $1.97 a$ & $63.15 a$ & $0.61 d$ \\
\hline $\mathrm{CV}(\%)$ & 4.95 & 12.53 & 26.75 \\
\hline \multirow{2}{*}{ Evaluations period (days) } & $\mathrm{PH}(\mathrm{cm})$ & PD (cm) & SN (unit) \\
\hline & \multicolumn{3}{|c|}{ Second crop } \\
\hline 120 & $1.84 d$ & $58.64 b$ & $13.18 c$ \\
\hline 150 & $2.28 c$ & $72.52 b$ & $14.70 \mathrm{~b}$ \\
\hline 180 & $2.70 \mathrm{~b}$ & $82.44 a$ & $16.14 a$ \\
\hline 210 & $2.83 a$ & $85.45 a$ & $16.22 a$ \\
\hline 240 & $2.83 a$ & $85.76 a$ & $16.36 a$ \\
\hline $\mathrm{CV}(\%)$ & 4.31 & 5.40 & 7.80 \\
\hline
\end{tabular}

*Means followed by the same letter within columns are not significantly different by Tukey's test $(p \leq 0.05)$.

The plant growth is greatly influenced by the use of different organic and inorganic mulching materials. They maintain soil moisture in the root zone of fruit plant. Water plays an important role in the growth and development of plants. The presence of adequate moisture in the soil is vital for plant growth and physiological processes (Bakshi et al. 2015).

Haynes (1980) observed that mulching generally increased the growth and vigor of various fruit plants. This author found that different types of organic or inorganic mulch provided higher values in the growth characteristics in banana plants. Helaly et al. (2017) observed an increase in plant length, stem diameter and leaf area of husk tomato (Physalis pubescens L.) plants, using black plastic film and white and black compared to the bare soil.

Santosh et al. (2017) concluded that the treatment $80 \%$ of fertilizer requirement application through drip and plastic mulch performed well in respect of growth parameters, maximum plant height, pseudostem girth of banana 'Grand Naine'. According to Chaurasia and Sachan (2020), the black plastic film and the organic mulch provided higher values for plant height and collar diameter than control of squash (Cucurbita pepo L.). Eid and El-Kholy (2018) observed higher values for the pseudostem diameter of the banana plants 'Williams' under black plastic film and organic mulch (banana leaves) compared to the control.

In the first and second crop, the mulches were efficient for banana growth. This technique can protect plants from adverse biotic and abiotic stresses and provide favorable environmental or growth conditions to the plants. Therefore, protected cultivation has significant plant multiplication enhancing vegetative and reproductive growth (Aman et al. 2018), once the mulches provide a more favorable environment for the plants to growth. Both organic or inorganic mulches conserve soil moisture.

In the second crop, higher values for plant height were observed for organic mulch, similar results were reported by other authors, such as Kwambe et al. (2015), who observed higher values of plant height for organic mulch (rice leftovers) and lower height for control in bean (Phaseolus vulgaris L.) in plants grown under organic and inorganic mulch. Kavutu and Mwangi (2018) observed higher values for number of leaves, number of runners, number of buds and number of flowers of strawberries (Fragaria $\times$ ananassa) for organic mulch (grass) than plastic mulches (black and clear) and both provided higher value characteristics than control.

Organic mulch enhances soil health by improving soil fertility and moisture and optimizing soil temperature with corresponding reduction in surface evaporation and nutrient loss (Montenegro et al. 2013). Organic matter is considered 
as ultimate determinant of soil fertility in most soils, which can be improved by organic mulch leading to better soil physical, chemical and biological properties (Albiach et al. 2000; Thy and Buntha 2005).

An increase was observed during the evaluation days for plant height, pseudostem diameter and leaf number in the first and second crop. The suckers number was greater at 150 days in the first crop (Table 3 ). This shows the normal growth of plants in the course of the days, reflecting the increase in these characteristics. Nevertheless, as for the suckers number, there was a decrease in the course of the days, which can be explained due to the common management practices of the banana farming that is the thinning.

There was interaction between days and mulches evaluations, contributing to an increase in leaf number in the first crop at 180 days using the plastics films. The plastic film (black) provided higher in the leaf number than control and organic mulch at 150 days. All treatments provided an increase in this characteristic at 150 and 180 days (Table 4 ).

Table 4. Leaf number and suckers number of Musa spp. of the first and second crop, under different mulches and evaluations period.

\begin{tabular}{|c|c|c|c|c|c|}
\hline \multirow{4}{*}{ Mulches } & \multicolumn{5}{|c|}{ Evaluations period (days) } \\
\hline & 60 & 90 & 120 & 150 & 180 \\
\hline & \multicolumn{5}{|c|}{ Leaf number (unit) } \\
\hline & \multicolumn{5}{|c|}{ First crop } \\
\hline Control (bare soil) & $11.13 \mathrm{aC}$ & $12.79 \mathrm{aB}$ & 13.96aAB & $14.67 \mathrm{bA}$ & $15.14 \mathrm{bA}$ \\
\hline Organic mulch & $10.71 \mathrm{aC}$ & $13.04 \mathrm{aB}$ & $13.75 \mathrm{aB}$ & $15.29 \mathrm{bA}$ & $15.31 \mathrm{bA}$ \\
\hline Plastic film (white and black) & $10.46 a \mathrm{D}$ & $13.92 \mathrm{aC}$ & $14.13 \mathrm{aC}$ & 15.79abB & $17.50 a A$ \\
\hline Plastic film (black) & $10.46 \mathrm{aC}$ & $13.92 \mathrm{aB}$ & $13.88 \mathrm{aB}$ & $16.75 \mathrm{aA}$ & $17.72 \mathrm{aA}$ \\
\hline $\mathrm{CV}(\%)$ & & & 5.67 & & \\
\hline \multirow{4}{*}{ Mulches } & \multicolumn{5}{|c|}{ Evaluations period (days) } \\
\hline & 60 & 90 & 120 & 150 & 180 \\
\hline & \multicolumn{5}{|c|}{ Suckers number (unit) } \\
\hline & \multicolumn{5}{|c|}{ Second crop } \\
\hline Control (bare soil) & $5.50 a A$ & $2.92 \mathrm{abB}$ & $4.85 \mathrm{bA}$ & $3.11 \mathrm{bB}$ & $3.04 \mathrm{bB}$ \\
\hline Organic mulch & $5.61 \mathrm{aA}$ & $2.76 \mathrm{bB}$ & $5.67 a b A$ & $2.49 b B$ & $2.49 \mathrm{bB}$ \\
\hline Plastic film (white and black) & $5.88 \mathrm{aA}$ & $3.54 a b B$ & $6.25 \mathrm{aA}$ & $6.25 \mathrm{aA}$ & $6.25 a A$ \\
\hline Plastic film (black) & $6.61 \mathrm{aA}$ & 4.13aB & $6.31 \mathrm{aA}$ & $6.31 \mathrm{aA}$ & $6.31 \mathrm{aA}$ \\
\hline $\mathrm{CV}(\%)$ & \multicolumn{5}{|c|}{18.95} \\
\hline
\end{tabular}

*Means followed by the same letter lower case in the columns (mulches) and upper case in the rows (evaluations days) are not significantly different by Tukey's test $(p \leq 0.05)$

Helaly et al. (2017) report an increase of the leaf area of husk tomato (P. pubescens L.) plants in plastic films, black and white and black, compared to control. The increments in vegetative growth parameters of banana, as a result of mulch treatments, may be due to plastic mulches directly affect on the microclimate around the plant by modifying the radiation budget of the surface and decreasing the soil water loss Liakatas et al. (1986).

The interaction between days and mulches evaluations were significant, contributing to an increase in suckers number in the second crop, at 210 and 240 days, using the plastics films. For the organic mulch and control, the greatest number of suckers was observed at 120 and 180 days, while for the plastic films the greatest suckers number was observed at 120 , 180, 210 and 240 days (Table 4).

\section{Postharvest quality}

There was no significant difference between the treatments for the postharvest characteristics in the first and second crop (Table 5). 
Table 5. Length, diameter, soluble solids (SS), titratable acidity (TA) and soluble solids/titratable acidity ratio (SS/TA) of fruits of Musa spp. of the first and second crops, under different mulches.

\begin{tabular}{|c|c|c|c|c|c|}
\hline \multirow{2}{*}{ Mulches } & Length (mm) & $\operatorname{Diam}(\mathrm{mm})$ & SS ( ${ }^{\circ}$ Brix $)$ & TA (\%) & SS/TA \\
\hline & \multicolumn{5}{|c|}{ First crop } \\
\hline Control (bare soil) & $113.31 a$ & $24.85 a$ & $17.94 a$ & $38.87 a$ & $0.48 a$ \\
\hline Organic mulch & $114.76 a$ & $25.31 a$ & $16.82 a$ & $39.01 a$ & $0.51 a$ \\
\hline Plastic film (white and black) & $117.00 a$ & $26.70 a$ & $18.86 a$ & $38.93 a$ & $0.46 a$ \\
\hline Plastic film (black) & 117.99a & $28.23 a$ & $19.63 a$ & $38.26 a$ & $0.43 a$ \\
\hline CV (\%) & 10.65 & 9.63 & 11.16 & 1.83 & 11.85 \\
\hline Mulches & \multicolumn{5}{|c|}{ Second crop } \\
\hline Control (bare soil) & $130.11 a$ & $36.10 a$ & $20.75 a$ & $38.62 a$ & $0.55 a$ \\
\hline Organic mulch & $125.74 a$ & $35.68 a$ & $21.39 a$ & $38.76 a$ & $0.54 a$ \\
\hline Plastic film (white and black) & $130.52 a$ & $36.16 a$ & $20.87 a$ & $38.72 a$ & $0.54 a$ \\
\hline Plastic film (black) & $141.62 a$ & $37.59 a$ & $21.19 a$ & $38.61 a$ & $0.55 a$ \\
\hline $\mathrm{CV}(\%)$ & 8.46 & 4.93 & 2.56 & 0.79 & 2.48 \\
\hline
\end{tabular}

${ }^{*}$ Means followed by the same letter within columns are not significantly different by Tukey’s test $(p \leq 0.05)$.

According to Aman et al. (2018), the plastic film mulch can promote early harvest of crop and improve yield and fruit quality. This was not observed in this work, but Helaly et al. (2017) observed increase in diameter, length, soluble solids and titratable acidity of husk tomato (P. pubescens $\mathrm{L}$.) fruits, cultivated using black plastic film and white and black compared to the bare soil. Santosh et al. (2017) concluded that the treatment with $80 \%$ of fertilizer requirement application through drip and plastic mulch provided higher levels of soluble solids but a lower titratable acidity of fruits of banana 'Grand Naine'.

Eid and El-Kholy (2018) observed an increase in length and diameter of banana fruits 'Williams', cultivated using black plastic film and organic mulch (banana leaves) under irrigation. The same authors report values of 19.33 and $18.50 \mathrm{~cm}$ of length and 3.58 and $3.48 \mathrm{~cm}$ of diameter for banana fruits grown on black plastic film and organic mulch, respectively. These values are close to those found in this experiment.

The values of the postharvest characteristics found in this study are within the values reported in the literature by researchers who worked with the postharvest characterization of banana fruits 'BRS Platina', such as Castricini et al. (2015), who observed this irrigated cultivar presents fruits of $22.23 \mathrm{~cm}$ of length, $39.42 \mathrm{~mm}$ of diameter and $23.18^{\circ} \mathrm{Brix}$ of soluble solids. According to Castricini et al. (2017), this cultivar irrigated in organic system showed fruits of $21.88 \mathrm{~cm}$ of length and $46.87 \mathrm{~mm}$ of diameter, both studies were carried out in the north of Minas Gerais. Lédo et al. (2018) observed values of $14.06 \mathrm{~cm}$ of length, $3.15 \mathrm{~cm}$ of diameter and $22.05^{\circ}$ Brix of soluble solids for banana fruits 'BRS Platina' irrigated in the state of Sergipe.

\section{Production and Productivity}

In the first crop, all the mulches provided an increase in the fruits number and number of hands than bare soil. For the production and productivity of the hands weight, the plastic films provided higher value for this characteristic than the control. However, the organic mulch provided an increase in the number of fruits, number of hands, production and productivity of hands weight than the other treatments in the second crop (Table 6).

Mulching is the process of covering the soil surface around the plants with an organic or synthetic material to create congenial condition for the plant growth, development and efficient production (Bakshi et al. 2015). This was proven in this study, since the mulches provided an increase in the yield parameters of banana. Other authors also observed an increase in the yield parameters of several crops grown under different types of plastic films than to the control, such as blueberry (Vaccinium corymbosum L) grown in reflective plastic film (Muneer et al. 2019), watermelon [Citrullus lanatus (Thunb.)] grown in white and black plastic film (Lambert et al. 2017) and husk tomato (P. pubescens L.) in plastic film black and plastic film white and black (Helaly et al. 2017). 
Table 6. Number of fruits (NF) and number of hands (NH), production of hands weight (HW) and productivity of hands weight (HW) of Musa spp. of the first and second crops, under different mulches.

\begin{tabular}{|c|c|c|c|c|}
\hline Mulchec & NF (unit) & NH (unit) & HW (kg) & HW (kg·ha-1) \\
\hline Mancies & \multicolumn{4}{|c|}{ First crop } \\
\hline Control (bare soil) & $63.70 b$ & $5.65 b$ & $4.55 b$ & $6083.81 \mathrm{~b}$ \\
\hline Organic mulch & $85.50 a$ & $6.95 a$ & $5.57 \mathrm{ab}$ & $7424.68 a b$ \\
\hline Plastic film (white and black) & $80.75 a$ & $6.55 a$ & $6.75 a$ & $8994.27 a$ \\
\hline Plastic film (black) & $78.75 a$ & $6.40 a$ & $6.40 a$ & $8534.27 a$ \\
\hline CV (\%) & 8.82 & 6.43 & 17.41 & 17.42 \\
\hline Mulches & \multicolumn{4}{|c|}{ Second crop } \\
\hline Control (bare soil) & $121.70 b$ & $8.46 b$ & $16.11 b$ & $21480.80 b$ \\
\hline Organic mulch & $140.67 a$ & $9.25 a$ & $20.47 a$ & $27283.74 a$ \\
\hline Plastic film (white and black) & $120.08 b$ & $8.33 b$ & $15.87 \mathrm{~b}$ & $21150.38 b$ \\
\hline Plastic film (black) & $120.13 b$ & $8.08 b$ & $16.13 b$ & $21501.29 b$ \\
\hline CV (\%) & 5.59 & 5.49 & 10.31 & 10.30 \\
\hline
\end{tabular}

*Means followed by the same letter within columns are not significantly different by Tukey's test $(p \leq 0.05)$.

The mulching provides a favorable environment for growth resulting in more vigorous and healthier plants, which may be more resistant to pest injury. Mulching prevents evaporation of water from the soil surface and also reduces the weed growth (Aman et al. 2018). This causes the plants to grow in more favorable environments due to the high humidity of the soil and less competition between the crop and weed, thus increasing crop yields.

The results of this study show that the organic mulch provided higher yields of the banana plants. This may have occurred because the organic mulches add nutrients and humus to the soil as they decompose, improving its moisture holding capacity, while inorganic mulches are inert materials originated from nonliving material, not adding nutrients and humus to the soil (Bakshi et al. 2014).

Another explanation for the different results from the first and second crops is that the plastic mulch had already been somewhat deteriorated, leaving the soil a bit uncovered, so this may have influenced the results of the second crop.

\section{CONCLUSION}

Both organic and inorganic (plastic film) mulch provide greater growth and yield of banana 'BRS Platina' not irrigated and can be used in the cultivation of this crop.

\section{AUTHORS' CONTRIBUTION}

Conceptualization: Pio L. A. S. and Pasqual M.; Methodology: Costa B. N. S. and Costa I. J. S.; Investigation: Costa B. N. S., Costa I. J. S., Abreu R. A. A. and Magalhães D. S.; Writing - Original Draft: Costa B. N. S., Costa I. J. S. and Melo E. T.; Writing Review and Editing: Pio L. A. S. and Pasqual M.; Funding Acquisition: Pio L. A. S.; Resources: Pio L. A. S.; Supervision: Pasqual M.

\section{DATA AVAILABILITY STATEMENT}

All dataset were generated or analyzed in the current study. 


\section{FUNDING}

Conselho Nacional de Desenvolvimento Científico e Tecnológico

https://doi.org/10.13039/501100003593

Fundação de Amparo à Pesquisa do Estado de Minas Gerais

https://doi.org/10.13039/501100004901

\section{REFERENCES}

Albiach, R., Canet, R., Pomares, F. and Ingelmo, F. (2000). Microbial biomass content and enzymatic activities after the application of organic amendments to a horticultural soil. Bioresource Technology, 75, 43-48. https://doi.org/10.1016/S0960-8524(00)00030-4

Aman, A., Sinha, S. and Rajan, R. (2018). Potentiality of protected cultivation in fruit crops: An overview. Journal of Pharmacognosy and Phytochemistry, 7, 3557-3560.

Bakshi, P., Bhat, D. J., Wali, V. K., Sharma, A. and Iqbal, M. (2014). Growth, yield and quality of strawberry (Fragaria x ananassa Duch.) cv. Chandler as influenced by various mulching materials. African Journal of Agricultural Research, 9, 701-706. https://doi.org/10.5897/ AJAR2013.7983

Bakshi, P., Wali, V. K., Iqbal, M., Jasrotia, A., Kour, K., Ahmed, R. and Bakshi, M. (2015). Sustainable fruit production by soil moisture conservation with different mulches: A review. African Journal of Agricultural Research, 10, 4718-4729. https://doi.org/10.5897/AJAR2014.9149

Bhattacharya, S., Das, S. and Saha, T. (2018). Application of plasticulture in horticulture: A review. The Pharma Innovation Journal, 7, 584-585.

Borges, A. L. and Souza, L. S. (2004). Exigências Edafoclimáticas. In O Cultivo da Bananeira (p. 15-23). Cruz das Almas: Embrapa.

Brodhagen, M., Goldberger, J. R., Hayes, D. G., Inglis, D. A., Marsh, T. L. and Miles, C. (2017). Policy considerations for limiting unintended residual plastic in agricultural soils. Environmental Science \& Policy, 69, 81-84. https://doi.org/10.1016/j.envsci.2016.12.014

Castricini, A., Santos, L. O., Deliza, R., Coelho, E. F. and Rodrigues, M. G. V. (2015). Caracterização pós-colheita e sensorial de genótipos de bananeiras tipo Prata. Revista Brasileira de Fruticultura, 37, 27-37. https://doi.org/10.1590/0100-2945-058/14

Castricini, A., Dias, M. S. C., Rodrigues, M. G. V. and Oliveira, P. M. (2017). Quality of organic banana produced in the semiarid region of Minas Gerais, Brazil. Revista Brasileira de Fruticultura, 39, e-813. https://doi.org/10.1590/0100-29452017813

Chaurasia, D. K. and Sachan, S. (2020). Effect of organic and inorganic mulching on growth, yield and economics of summer squash (Cucurbita pepo L.) in open field condition of mid hills of Uttarakhand. The Journal of Rural and Agricultural Research, 20, 22-25.

Eid, T. A. and El-Kholy, M. F. (2018). Effect of Some Mulching Treatments on Water use Efficiency, Growth, Yield and Fruit Quality of Williams Banana Plant. Middle East Journal of Agriculture Research, 7, 117-131.

Ekebafe, L. O., Ogbeifun, D. E. and Okieimen, F. E. (2011). Polymer Applications in Agriculture. Biokemistri, 23, 81-89.

EMBRAPA. (2013). Sistema Brasileiro de Classificação de Solos. Brasília: Embrapa Solos. [Accessed Jan. 20, 2020]. Available at: http:// livimagens.sct.embrapa.br/ amostras/00053080.pdf

Fang, S., Xie, B. and Zhang, H. (2007). Nitrogen dynamics and mineralization in degraded agricultural soil mulched with fresh grass. Plant and Soil, 300, 269-280. https://doi.org/10.1007/s11104-007-9414-2

Ferreira, D. F. (2011) SISVAR: a computer statistical analysis system. Ciência e Agrotecnologia, 35, 1039-1042. https://doi.org/10.1590/ S1413-70542011000600001 
Haynes, R. J. (1980). Influence of soil management practice on the orchard agro-ecosystem. Agro-Ecosystems, 6, 3-32. https://doi. org/10.1016/0304-3746(80)90003-7

Helaly, A. A., Goda, Y., Abd El-Rehim, A. S., Mohamed, A. A. and El-Zeiny, O. A. H. (2017). Effect of polyethylene mulching type on the growth, yield and fruits quality of Physalis pubescens. Advances in Plants \& Agriculture Research, 6, 154-160. https://doi.org/10.15406/ apar.2017.06.00229

Kader, M. A., Senge, M., Mojid, M. A. and Ito, K. (2017). Recent advances in mulching materials and methods for modifying soil environment. Soil and Tillage Research, 168, 155-166. https://doi.org/10.1016/j.still.2017.01.001

Kavutu, A. and Mwangi, M. (2018). Effects of Grass and Plastic Mulch on Growth and Yield of Strawberries (Fragaria x ananassa) in Kiambu County, Kenya. Journal of Animal \& Plant Sciences, 38, 6129-6137.

Köppen, W. and Geiger, R. (1928). Klimate der Erde. Gotha: Verlag Justus Perthes.

Kwambe, X. M., Masarirambi, M. T., Wahome, P. K. and Oseni, T. O. (2015). The effects of organic and inorganic mulches on growth and yield of green bean (Phaseolus vulgaris L.) in a semi-arid environment. Agriculture and Biology Journal of North America, 6, 81-89.

Instituto Nacional de Meteorologia - INMET. Banco de dados meteorológicos para ensino e pesquisa. [Accessed Jan. 20, 2020]. Available at: http://www.inmet.gov.br/portal/index.php?r=bdmep/bdmep

EMBRAPA. (2013). Sistema Brasileiro de Classificação de Solos. Brasília: Embrapa Solos. [Accessed Jan. 20, 2020]. Available at: http:// livimagens.sct.embrapa.br/ amostras/00053080.pdf

Lambert, R. A., Barro, L. S., Carmo, K. S. G., Oliveira, A. M. S. and Borges, A. A. (2017). Mulching é uma opção para o aumento de produtividade da melancia. Revista de Agricultura Neotropical, 4, 53-57. https://doi.org/10.32404/rean.v4i1.1184

Lédo, A. S., Silva, T. N., Martins, C. R., Silva, A. V. C., Lédo, C. A. S. and Amorim, E. P. (2018). Physcochemical characterization of banana friut by univariate and multivariate procedures. Bioscience Journal, 34, 24-33. https://doi.org/10.14393/BJ-v34n1a2018-37232

Liakatas, A., Clark, J. A. and Monteith, J. L. (1986). Measurements of the heat balance under plastic mulches. Part I. Radiation balance and soil heat flux. Agricultural and Forest Meteorology, 36, 227-239. https://doi.org/10.1016/0168-1923(86)90037-7

Liang, Y. L., Zhang, C. E. and Guo, D. W. (2002). Mulch types and their benefit in cropland ecosystems on the Loess Plateau in China. Journal of Plant Nutrition, 25, 945-955. https://doi.org/10.1081/PLN-120003930

Lorena, D. R., Silva, C. L., Peixoto, J. R., Oliveira, G. P. and Rios, G. F. A. (2016). Influence of irrigation and potassium fertilization on the production and quality of banana fruit in Brasília. Revista Engenharia na Agricultura - Reveng, 24, 463-472. https://doi.org/10.13083/ reveng.v24i6.718

Montenegro, A. A. A., Abrantes, J. R. C. B., Lima, J. L. M. P., Singh, V. P. and Santos, T. E. M. (2013). Impact of mulching on soil and water dynamics under intermittent simulated rainfall. Catena, 109, 139-149. https://doi.org/10.1016/j.catena.2013.03.018

Muneer, S., Kim, J. H., Park, J. G., Shin, M. H., Cha, G. H., Kim, H. L., Ban, T., Kumarihami, H. M. P. C., Kim, S. H., Jeong, G. and Kim, J. G. (2019). Reflective plastic film mulches enhance light intensity, floral induction, and bioactive compounds in 'O'Neal' southern high bush blueberry. Scientia Horticulturae, 246, 448-452. https://doi.org/10.1016/j.scienta.2018.10.042

Ni, X., Song, W., Zhang, H., Yang, X. and Wang, L. (2016). Effects of Mulching on Soil Properties and Growth of Tea Olive (Osmanthus fragrans). PLoS ONE, 11, e0158228. https://doi.org/10.1371/journal.pone.0158228

Pakdel, P., Tehranifar, A., Nemati, H., Lakzian, A. and Kharrazi, M. (2013). Effect of different mulching materials on soil properties under semi-arid conditions in northeastern Iran. Wudpecker Journal of Agricultural Research, 2, 80-85.

Pervaiz, M. A., Iqbal, M., Shahzad, K. and Hassan, A.-U. (2009). Effect of Mulch on Soil Physical Properties And N, P, K Concentration in Maize (Zea mays L.) Shoots Under Two Tillage Systems. International Journal of Agriculture \& Biology, 11, 119-124. 
Ranjan, P., Patle, G. T., Prem, M. and Solanke, K. R. (2017). Organic Mulching - A Water Saving Technique to Increase the Production of Fruits and Vegetables. Current Agriculture Research Journal, 5, 371-380. https://doi.org/10.12944/CARJ.5.3.17

Santosh, D. T. and Tiwari, K. N. (2017). Response of tissue cultured banana (Musa acuminate L.) cv. Grand Naine to different levels of nutrients under drip fertigation and black plastic mulch. Applied Ecology and Environmental Research, 15, 1473-1488. https://doi. org/10.15666/aeer/1504_14731488

Steinmetz, Z., Wollmann, C., Schaefer, M., Buchmann, C., David, J., Tröger, J., Muñoz, K., Frör, O. and Schaumann, G. E. (2016). Plastic mulching in agriculture. Trading short-term agronomic benefits for long-term soil degradation? Science of the Total Environment, 550 , 690-705. https://doi.org/10.1016/j.scitotenv.2016.01.153

Thy, S. and Buntha, P. (2005). Evaluation of fertilizer of fresh solid manure, composted manure or biodigester effluent for growing Chinese cabbage (Brassica pekinensis). Livestock Research for Rural Development, 17, 149-154. http://www.Irrd.org//rrd17/3/sant17026.htm Von Loesecke, H. W. (1950). Bananas, Chemistry, Physiology, Technology. Geneva: Interscience Publishers.

Wang, Y. P., Li, X. G., Fu, T., Wang, L., Turner, N. C., Siddique, K. H. M. and Li, F.-M. (2016). Multi-site assessment of the effects of plasticfilm mulch on the soil organic carbon balance in semiarid areas of China. Agricultural and Forest Meteorology, 228-229, 42-51. https:// doi.org/10.1016/j.agrformet.2016.06.016 